\title{
The Textualization of Priestly Ritual in Light of Hittite Sources*
}

\author{
Yitzhaq Feder \\ University of Haifa \\ Draft Version, to be published in: \\ Ritual and Text in the Pentateuch (eds. C. Nihan \& J. Rhyder; Winona Lake, Ind.: Eisenbrauns)
}

\section{Introduction}

Imagine the cover-up of the century. What if yet another cave had been discovered in Qumran, but its contents were so startling that they were never revealed to the public? What if, in this cave, was found the genizah of the Priestly school, containing the discarded rough drafts of ritual texts which ultimately were included - in a much more polished form - in the Priestly materials of the Pentateuch? What would be the implications of such a discovery?

While this scenario is a mere fantasy of a biblical scholar, we do have some very real evidence which might shed light on the formative phases of the Priestly source (P). ${ }^{1}$ The aim of this paper is to offer a preliminary assessment of how the study of Hittite ritual

\footnotetext{
* I thank Amir Gilan and Shai Gordin for sharing their extensive knowledge and insight during the preparation of this paper.

${ }^{1}$ In this article, I will use Priestly writings or P to include also the Holiness Source (H) and possibly later layers. In the final section, a more differentiated view will be presented, as will be clear from the context.
} 
traditions can contribute to the study of the formation of Priestly ritual texts. Research into the formation and transmission of the Hittite ritual texts has made remarkable progress in the past fifteen years and is blessed with both a rich body of primary data and a growing scholarly interest in the relationship between ritualistic and scribal activity.

Before presenting this evidence in more detail, it may be helpful to compare the much more meager evidence with which biblical scholars have accustomed themselves. The textual variants from the Masoretic text of P (Samaritan, LXX, Qumran) are from the late Second Temple period at the earliest, and aside from a few notable exceptions, offer little direct insight into the formative period of the Priestly text. As such, the primary source of information regarding the prehistory of $\mathrm{P}$ is the existence of inconsistencies within and between different Priestly texts. How these inconsistencies are assessed vary on a spectrum from more harmonistic approaches such as that of David Zvi Hoffmann to the detailed stratification of layers of Karl Elliger. While one may highly value (as I do) the ingenuity involved in critical methods and accept the plausibility of their conclusions, the fact remains that without an external frame of reference it is difficult to know what is the real significance of these inconsistencies.

Here lies the key interest of the Hittite ritual texts. Not only do individual "manuscripts" (cuneiform tablets) attest to the types of inconsistencies identified by biblical scholars, but more importantly, the Hittite archives have yielded multiple parallel copies to particular ritual compositions with very significant variants. These variants can even be dated to specific stages in the development of the Hittite cuneiform script.

The archives of the Hittite capital Hattuša (modern Boğazköy) have yielded hundreds of ritual compositions written on cuneiform tablets, supplying modern 
scholarship with the largest corpus of ritual texts known from the ancient Near East. This corpus spans from the $16^{\text {th }}$ cent. BCE to the collapse of the Hittite empire around 1200 , with most of the surviving texts pertaining to the latter phase. A given ritual composition may be attested on one tablet or on over a dozen roughly parallel copies, reflecting often minor but sometimes major variations. The implications of these variants for the study of the transmission and scribal activity responsible for these texts has been subjected to several important studies in recent years, as will be discussed in some detail below.

At this point, it will be useful to offer a general categorization of the textual materials at our disposal. The Hittite scribes distinguished between "festivals" $\left(\mathrm{EZEN}_{4}\right)$ and "ritual" (SISKUR/ SÍSKUR) texts. Gary Beckman elucidates this difference as follows:

Modern scholars have observed that, with rare exceptions, festivals are ceremonies of the state cult, to be performed periodically - monthly, yearly, or on the occasion of particular recurrent natural events...or agricultural activities. In contrast, rituals are to be carried out only in response to special crises affecting an individual or group - impotence, miscarriage, strife within a family, a lost battle, and so on. ${ }^{2}$

Both of these sub-genres find parallels in P. Regarding the latter, I would suggest substituting the designation "cultic" for "festival," to designate both the instructions for regular offerings of the official cult (for example, Lev 1-3) as well as festival instructions, strictly defined (Lev 23; Num 28-29). The designation "ritual" can be applied to irregular offerings such as those for expiation (for example, Lev 4-5) and purification rites (Lev 12-

\footnotetext{
${ }^{2}$ G. Beckman, The babilili-Ritual from Hattusa (Winona Lake, IN: Eisenbrauns, 2014), 1.
} 
15), including those for unique circumstances, such as those for the suspected adulteress (Num 5:11-31) or the nazirite (Num 6:1-21).

These terminological parallels are not mere exercises in classification for its own sake, but rather invite more sustained cross-cultural comparisons with important implications for the meaning and historical background of P's ritual practices and their textualization. Whereas cultic practices focus on paying homage to a given deity and ensuring the continuance of divine favor, rituals usually attend to emergent situations that are of dire concern to the patron(s). These distinct functions find expression in formal differences between these genres. For example, while the ritual texts are usually introduced with casuistic formulas, cultic texts are generally introduced by reference to the calendric date(s) or season(s) of their performance. ${ }^{3}$ While this distinction between festivals and rituals is crucial for understanding the ancient evidence, the present essay will employ the term "ritual" as an inclusive analytic category which encompasses these two types,

${ }^{3}$ More precisely, several different types of texts related to festivals can be identified, including: outline tablets for multiple festivals, outline tablets for a single complex festival, detailed descriptions of particular days within a festival, ration tablets and other administrative and oracle documents. See D. Schwemer, "Quality Assurance Managers at Work: The Hittite Festival Tradition," in Liturgie oder Literature: Die Kultrituale der Hethiter im transkulturellen Vergleich (ed. G.G.W. Müller; Studien zu den BoğazköyTexten 60. Wiesbaden: Harrasowitz, 2016) 7-12. My reference here to "cultic" texts (as contrasted with therapeutic rituals) refers specifically to the detailed daily descriptions, which comprise the bulk of the Hittite festival corpus. 
consistent with its use in modern academic discourse ('ritual' studies). When necessary to distinguish sub-genres, the designation "therapeutic rituals" will be used.

Before presenting current research on Hittite ritual texts, it may be useful to raise some fundamental questions that a biblical scholar may want to ask regarding this evidence:

- Who produced these ritual texts, and why?

- What type of authority (if any) was ascribed to these texts?

- What can the variation between exemplars teach us regarding the roles of oral and written transmission of these traditions?

These topics have been addressed by the current wave of Hittitological research, yet the richness of the textual data has enabled Hittitologists to formulate even more focused questions. Some of these studies have dealt with the origins of these texts, specifically the role of ritualists and scribes in producing them. A key question is whether these rituals originated as descriptions of rituals, produced either by observation of their performance or by interviewing the practitioner, or as a prescriptive ritual in which the scribes took more liberty in their formulation. A related question which has been asked regarding particular rituals, such as the royal funerary ritual ( $\check{s}$ allišs waštai $\check{s})$, is whether these texts originated in reference to a particular performance involving a named monarch, only later to be transformed into a generic text, or vice versa: the name of a specific monarch was later added to an originally generic ritual tradition. ${ }^{4}$ Other studies have focused on the question

4 For the royal funerary ritual, see T. van den Hout, "Death as a Privilege," in Hidden Futures: Death and Immortality in Ancient Egypt, Anatolia, the Classical, Biblical 
of the transmission of these rituals, specifically on the role of visual copying, dictation and memorization in the production of multiple versions of a single textual tradition. To make life more interesting, the conclusions reached by scholars to these questions have not always been the same, requiring that each ritual tradition be evaluated on a case-by-case basis. At any rate, before drawing analogies to Priestly ritual, it is necessary to review this research in more detail.

The review of research on Hittite rituals is divided into two sections. The following section attempts to characterize the role of scribes in the production of ritual texts and deals with the vexed question of the authorship of these rituals. The subsequent section focuses on the function of ritual texts, specifically their relationship to ritual practice. Put differently, these two lines of inquiry can be framed as questions:

1) How were the Hittite ritual texts composed?

2) Why were they composed?

As will be seen, these topics can be dealt with largely independently of one another.

and Arabic-Islamic World (ed. J.M. Bremmer, T. van den Hout and R. Peters; Amsterdam: Amsterdam University Press, 1994) 37-75; ibid., "Zu einer Stratigraphie der hethitischen Totenrituale," in Saeculum. Gedenkschrift für Heinrich Otten anlässlich seines 100. Geburtstags (ed. A. Müller-Karpe, E. Rieken, and W. Sommerfeld; Studien zu den Boğazköy-Texten 58; Wiesbaden: Harrassowitz, 2015) 301-6; A. Kassian, A. Korolëv, and A. Sidel’tsev, Hittite Funerary Ritual: šalliš waštaiš (AOAT 288; Münster: UgaritVerlag, 2002). 


\section{Scribal Activity in the Production of Ritual Texts}

Probably the most fundamental question that needs to be addressed pertains to the relative contributions of the ritualists and scribes in the formation of these texts. Were the scribes merely responsible for transcribing the dictated words of ritualists and for the mechanical process of duplicating texts, or did they take a more creative role in the production of these texts? Put in extreme terms, we may ask whether the ritual texts are the ipsissima verba of the ritualists, written and duplicated faithfully by scribal secretaries, or, to take the more skeptical stance, were these rituals scribal inventions, such that the ritualist 'authors' were mere literary fictions? ${ }^{5}$

While there may be heuristic value in drawing a strict dichotomy between viewing the textualization of ritual traditions as a mechanical vs. creative process, it is obvious that reality was much more complicated. Between the two extremes, there was a wide spectrum of scribal functions. A helpful framework for surveying the relevant data can be taken from Karl van der Toorn's study of scribal culture, which can be reorganized to depict escalating degrees of scribal intervention as follows:

1) transcription of oral lore (dictation);

2) production of duplicates

3) compilation of existing lore, either oral or written;

${ }^{5}$ So K. Hecker, "Tradition und Originalität in der altorientalischen Literature," Archív Orientální 45 (1977), 248-49. 
4) integration of individual documents into more comprehensive compositions;

5) expansion of an inherited text;

6) adaptation of an existing text for a new audience/ situation

7) invention of a new text. ${ }^{6}$

\subsection{The Scribes as Secretaries and Copyists}

A major breakthrough in the study of Hittite rituals was Jared Miller's 2004 monograph Studies in the Origin, Development and Interpretation of the Kizzuwatna Rituals, focusing on the Hittite rituals which originated in the area of Kizzuwatna (classical Cilicia) in southeastern Anatolia. ${ }^{7}$ As implied by the title, Miller devotes considerable attention to the problem of origins, specifically whether these rituals originated as strict records of the words of ritual practitioners (conveyed by interviews or dictation) or as more freely composed scribal constructs. Miller conducts this inquiry by means of a two-pronged approach: first, by means of detailed examinations of specific textual compositions as represented in parallel versions; secondly, by a broad survey of formal and grammatical characteristics represented in the Kizzuwatna texts.

\footnotetext{
${ }^{6}$ K. van der Toorn, Scribal Culture and the Making of the Hebrew Bible (Cambridge, MA: Harvard University Press, 2007) 110-41. The fifth of these (“expansion") will not be thematized below, since it is discussed in reference to several of the other functions.

7 Studies in the Origins, Development and Interpretation of the Kizzuwatna Rituals (Studien zu den Boğazköy-Texten 46; Wiesbaden: Harrassowitz, 2004).
} 
Starting with the first type of evidence, what can be observed by the comparison of textual variants? In comparing variants of the Maštigga Ritual Against Domestic Quarrel (KBo 39.8++), Miller finds both minor (orthographic and linguistic) and major variants. The latter category includes:

- Differences in the number of ritual patrons (one or two)

- The absence in a group of copies of numerous sections at the beginning of the text (§§ 2-11), containing the list of paraphernalia and the beginning of the ritual.

- Changes in sequence of sections in the ritual ${ }^{8}$

- Lack of full correspondence between the list of paraphernalia and the materials used in the ritual sections of the text

Though Miller seeks to mine this data for its implications regarding the origins of the ritual texts, ${ }^{9}$ it is not clear that the textual variants analyzed in this section of his work are reflective of the origins of this textual tradition. As pointed out by Miller himself, many of the major variants (for example, the discrepancy between one or two ritual patrons) are attested already in the earliest manuscript evidence (from the Middle Hittite period; ca. $14^{\text {th }}$ cent. BCE), such that the formative phase of this textual tradition remains obscure. In other words, these manuscripts are at least a few generations removed from their original composition.

\footnotetext{
${ }^{8}$ See especially the comparisons of Text 1 and Text 2 (Ibid., 244-251).

${ }^{9}$ See, for example, Ibid., 253.
} 
More fundamentally, as pointed out by Hannah Marcusson and Theo van den Hout in their reevaluation of this data, these textual variants are much more informative of the process of transmission of these textual traditions. ${ }^{10}$ Building on an earlier study of Sumerian textual criticism by Paul Delnero, ${ }^{11}$ Marcuson and van den Hout argue that the differences between duplicates of ritual texts are best understood as memory variants. ${ }^{12}$ However, despite their careful analysis, it is often difficult to isolate memory variants from other forms of copying "errors. ${ }^{13}$ Furthermore, the existence of additions and corrections to these manuscripts indicates that they have been (visually) proofread in comparison with their Vorlagen. ${ }^{14}$ More generally, we should be wary of exaggerating the distinction

10 "Memorization and Hittite Ritual: New Perspectives on the Transmission of Hittite Ritual Texts.” JANER 15 (2015) 143-68.

11 "Memorization and the Transmission of Sumerian Literary Compositions," JNES 71 (2012) 198-208.

${ }^{12}$ For a similar view regarding the relationship of KBo 13.145 to the Hantitaššu ritual tradition, see B. J. Collins, "The Place of KBo 13.145 in the Hantitašš Text Tradition," in Beyond Hatti: A Tribute to Gary Beckman (ed. B. J. Collins and P. Michalowski; Atlanta: Lockwood Press, 2013) 63-74.

${ }^{13}$ M. Worthington, Principles of Akkadian Textual Criticism (Berlin: de Gruyter, 2012) $13-16$.

${ }^{14}$ Note for example the omission of the conjunctive -ia in MS II.B i 2 (KUB 12.34) of the Maštigga ritual (Marcuson and van den Hout, "Memorization and Hittite Ritual," 151), which was then added above the line (Miller, Studies, 61, n. 94). For further discussion of 
between visual copying and memorization, since these complementary processes often took place in tandem, as has been repeatedly stressed by David Carr. ${ }^{15}$ Nonetheless, the important point for our purposes is that many differences between duplicates and even internal inconsistencies (for example, between paraphernalia lists and their corresponding ritual descriptions) could be explained as mere accidents of the copying process, not as deliberate editorial changes made by scribes.

\subsection{Scribes as Compilers}

On the other hand, there are numerous points of evidence - both explicit and implicit - for more active participation of scribes in the production of these texts. For example, there is ample evidence for the role of scribes as compilers, integrating originally independent rituals. In particular, such a process of compilation might account for internal inconsistencies found in texts, such as the alternation between single and multiple ritual patrons and the vacillation between $1^{\text {st }}, 2^{\text {nd }}$ and $3^{\text {rd }}$ person grammatical forms. While some cases may be best explained as deliberate scribal adaptations of an existing ritual (see below), at least some of the inconsistencies appear to reflect the attempt of scribes to

proof-reading, see S. Gordin Hittite Scribal Circles: Scholarly Tradition and Writing Habits (Studien zu den Boğazköy-Texten 59; Wiesbaden: Harrassowitz, 2015) 33-34.

${ }^{15}$ Writing on the Tablet of the Heart: Origins of Scripture and Literature (New York: Oxford University Press, 2005); The Formation of the Hebrew Bible: A New Reconstruction (Oxford: Oxford University Press, 2011). 
integrate distinct documents into a single ritual text. ${ }^{16}$ For example, while discrepancies between paraphernalia lists and the corresponding ritual instructions might be explained ostensibly as lapses of memory on the part of the scribes, it is worth noting that the colophon of one ritual (KUB 41.21 iv 16'-18') explicitly notes that the utensil list was written on a separate tablet: "Words of Allaiturahhi. The ritual paraphernalia (are on) another tablet." ${ }^{17}$ Likewise, some texts appear to be combinations of separate rituals for distinct deities (for example, CTH 391). ${ }^{18}$

The explicit references to the consultation of tablets provide incontrovertible evidence to the scribal function as compilers. ${ }^{19}$ These references break the continuity of a ritual text to note that certain information - the instructions for a specific rite or a list of paraphernalia - are recorded on a separate tablet. For example, the Hittite birth ritual KBo $17.65+$ makes several references to additional tablets. Most interestingly, the ritual concludes with the requirement to celebrate the 'Fertility Festival,' but notes that the precise instructions are found in the archives of Kizzuwatna:

${ }^{16}$ B. Christiansen, Die Ritualtradition der Ambazzi: Eine philologische Bearbeitung und entstehungsgeschichtliche Analyse der Ritualtexte CTH 391, CTH 429 und CTH 463 (Studien zu den Boğazköy-Texten 48; Wiesbaden: Harrassowitz, 2006) 122.

${ }^{17}$ See Miller, Studies, 512.

${ }^{18}$ See J.L. Miller, Review of Die Ritualtradition der Ambazzi: Eine philologische Bearbeitung und entstehungsgeschichtliche Analyse der Ritualtexte CTH 391, CTH 429 und CTH 463, by B. Christiansen. ZA 99 (2009) 155-56.

${ }^{19}$ See Miller, Studies, 511-523. 
But when (they celebrate) the Fertility Festival, when she [gi]ves birth, how they celebrate the festival is recorded on a writing-board (kurta-), and it is (in) Kizzuwatna. I am unable to recite it by heart, so they will bring it from there. ${ }^{20}$

This use of cross-referencing can be illuminated further by comparison with the ritual texts found in neighboring cultures, for example the deity lists from Ugarit, ${ }^{21}$ which will be discussed later. These systems of intertextual cross-referencing suggest a scholarly milieu in which the production of texts involved collation of discrete documents, even those from distant archives, and the practice of ritual could involve the synthesis of information garnered from the simultaneous comparison of these texts.

\subsection{Adapting a Ritual to a New Situation}

Furthermore, the Hittite scribes did not shy away from adapting an existing tradition to a new situation. This role is demonstrated clearly by cases of discrepancies between parallel copies of a particular ritual, where one version refers to the ritual patron generically and another refers to a specific king, queen or member of the royal family. In these cases, it is typically assumed that one of the versions is the more original, leaving the question

${ }^{20}$ KBo 17.65+ obv. 37-39/ rev. 45-46. Text edition: G. Beckman, Hittite Birth Rituals (Studien zu den Boğazköy-Texten 29; Wiesbaden: Harrassowitz, 1983) 136, 144; translation adapted from Miller, Studies, 518, based on the composite text.

${ }^{21}$ Dennis Pardee, Ritual and Cult at Ugarit (Writings from the Ancient World 10; Atlanta: SBL, 2002), 11-24. 
whether a historical event has been reformulated as a generic ritual or whether a generic ritual has been reformulated in reference to specific historical figures. Interestingly, studies of these cases have led to contradictory conclusions. For example, Billie Jean Collins' study of the Hantitaššu ritual identifies it as an example of "royal co-option of a popular ritual." ${ }^{22}$ On the other hand, Stefano de Martino's and Aygül Süel's edition of the third tablet of the Itkalzi Ritual distinguishes between a) a long and presumably original series of 22 tablets taken to Hattuša from Šapinuwa written only in Hurrian, and b) a shortened series of 10 tablets with prescriptive portions written in Hittite and incantations in Hurrian. ${ }^{23}$ The main difference between the two series is that the longer Hurrian version

22 "Royal Co-option of a Popular Ritual: The Case of Hantitaššu," in Proceedings of the Eighth International Congress of Hittitology, Warsaw, 5-9 September 2011 (ed. P. Taracha and M. Kapełus; Warsaw: Agade, 2014), 185-201. See also B. Christiansen, "Ein Ensuhnungsritual fur Tuthaliya und Nikalmati? Betrachrungen zur Entstehungsgeschichte von KBo 15.10+,"SMEA 49 (2007) 93-107. For the apparent adaptation of a ritual of Allaiturahhi dedicated to Šuppiluliumma II (CTH 781), see V. Haas, "Die hurritischhethitischen Rituale der Beschwörerin Allaiturah(h)i und ihr literarhistorischer Hintergrund," in Hurriter und Hurritisch (ed. V. Haas; Konstanzer Althistroische Vorträge und Forschungen 21; Konstanz: Xenia, 1988) 120; G. Torri, "Subject Shifting in Hittite Magical Rituals," in Tabularia Hethaeorum. Hethitologische Beiträge. Silvin Košak zum 65 Geburtstag (ed. D. Groddek and M. Zorman; Dresdner Beiträge der Hethitologie 25; Wiesbaden: Harrassowitz, 2007) 672.

${ }^{23}$ The Third Tablet of the itkalzi Ritual (LoGisma: Torino, 2015) 15-17. 
frequently mentions the ritual patrons, Queen Tadu-Hูeba and King Tašmi-šarri, whereas the shorter bilingual version employs the generic fill-in-the-blank designation "ritual patron." de Martino and Süel draw the likely conclusion that the bilingual is an adaptation of the original which focused on the specific royal couple. ${ }^{24}$ Accordingly, it seems necessary to consider the possibility that such processes of textual adaptation could be carried out in both directions. More fundamentally, these processes indicated the active role of scribes in revising ritual texts.

\subsection{Scribes as Ritual Inventors?}

But the role of scribes may have been even more extensive than transcription, compilation and adaptation. Put differently, despite the quotation formulas employed in the incipits and colophons attributing the text to specific ritual experts, scholars have begun to cast doubt on the assumption that these ritualists were the actual authors of the words attributed to them.

In twentieth-century research, the issue of the formation of ritual texts was often conceptualized in light of Baruch Levine's distinction between descriptive and prescriptive texts. Based on comparative evidence from Ugarit, Hatti and Mesopotamia, Levine claimed that the descriptive rituals in the Bible were based on archival documents. ${ }^{25}$ However, after

\footnotetext{
${ }^{24}$ Ibid., 17.

25 B.A. Levine, "Ugaritic Descriptive Rituals," JCS 17 (1963) 105-11; idem, "The Descriptive Tabernacle Texts of the Pentateuch," JAOS 85 (1965) 307-18.
} 
several decades of further research, it would appear that the corpus of descriptive rituals is exceedingly slim (if it exists at all). As for the Ugaritic evidence, Dennis Pardee, representative of the general tendency in Ugaritic scholarship, classifies "the vast majority of these texts as prescriptive in nature. ${ }^{, 26}$ Indeed, in his own more recent discussion of the topic, Levine subtly backtracks from his earlier distinction, referring to the "process by which descriptive rituals gradually appropriate prescriptive formulations as their functional role comes to determine their formal structure to an ever greater extent." ${ }^{27}$ David Clemens unpacks this dense restatement as follows:

A more fundamental modulation of [Levine's] previous position concerns his understanding of the term 'descriptive' itself, acknowledged to have been 'problematic since the outset.' Apparently the adjective was used to describe the form rather than the function of the texts; and he concedes that they are prescriptive in function, which is evidenced formally by the occurrence of jussive forms. This

${ }^{26}$ Ritual and Cult, 25; see also D. M. Clemens, Sources for Ugaritic Ritual and Sacrifice. Vol. 1: Ugaritic and Ugarit Akkadian Texts (AOAT 284/1; Münster: Ugarit-Verlag, 2001) 105 , n. 506.

27 “The Descriptive Ritual Texts from Ugarit: Some Formal and Functional Features of the Genre," in The Word of the Lord Shall Go Forth: Essays in Honor of David Noel Freedman in Celebration of his Sixtieth Birthday (ed. C.L. Meyers and M. O’Connor; Winona Lake: Eisenbrauns, 1983) 469. 
being the case, it is difficult to see why the distinction between descriptive and prescriptive is belabored at all. ${ }^{28}$

As far as the Hittite texts are concerned, Jared Miller devotes considerable attention to debunking the descriptive paradigm, whether based on eye-witness "ethnographic" records or a strict transcription of the ritualist's words. Here Miller's detailed survey of formal and grammatical aspects of the Kizzuwatna rituals is particularly illuminating. ${ }^{29}$ For example, the Hittite rituals are usually attributed to a particular ritualist or group of ritualists. The typical incipit begins by attributing the ritual to a named ritualist (UMMA PN), followed by a protasis stating the purpose of the ritual and a brief apodosis introducing the ritual instructions, usually phrased in the $1^{\text {st }}$ person. For example, the Ritual of Maštigga for Domestic Quarrel opens as follows:

Thus (speaks) Maštigga, woman of Kizzuwatna: 'When a father and a son, or a man and his wife, or a brother and sister quarrel: when I reconcile them, I treat them thus. I take the following: ${ }^{30}$

The colophon is closely modeled after the incipit. It typically states the sequence number of the tablet and whether or not this tablet constitutes the end of the ritual. This information is followed by the 'name' of the ritual, attributing it to the ritualist (AWAT/INIM [ $\check{s} a] \mathrm{PN})$

${ }^{28}$ Clemens, Sources for Ugaritic Ritual, 105.

${ }^{29}$ Miller, Studies, 469-532.

${ }^{30}$ According to MS II.B, based on the edition and translation of Miller (Studies, 61-62), with minor adaptations. 
and restating the protasis from the incipit. The colophon concludes by identifying the scribe responsible for the tablet. ${ }^{31}$ Here is the colophon of the same manuscript:

First tablet: the word of Maštigga, woman of Kummanni (entitled): 'If a father and son, or a husband and his wife or a brother and sister quarrel, when I bring them together, and I treat them as such. Finished: Hand of Han[ikkuili, the Scribe], son of NU.[ $\left.{ }^{\mathrm{GIS}} \mathrm{SAR}\right] .^{32}$

As will be seen, these ascriptions of authorship and function are often at least partially incongruent with the contents of the ritual texts.

Despite the close correspondence between the incipits and colophons, usually formulated in the $1^{\text {st }}$ person, the bodies of ritual texts do not generally follow the $1^{\text {st }}$ person format, but rather discuss the ritual activities in the $3^{\text {rd }}$ person, though there are exceptions. Moreover, in many cases, the ritual activities are performed by a different type of officiant than that of the 'speaker.' For example, a ritual attributed to an 'old woman' (ŠU.GI) may be carried out by male priests. However, several texts revert (temporarily) to the first person in presenting the list of paraphernalia to be used in the ritual ("then I bring..."). Some texts change unexpectedly to the $2^{\text {nd }}$ person. Since the $2^{\text {nd }}$ person is more common in Mesopotamian rituals, scholars have wondered if these texts may be betraying an

\footnotetext{
${ }^{31}$ For a typical structure of Hittite ritual colophons and incipits, see W. Waal, The Source as Object. Studies in Hittite Diplomatics (Ph.D. diss., Leiden University, 2010) 236-250; Gordin, Hittite Scribal Circles, 39-50.

32 According to MS II.B, with minor reconstructions (unmarked) based on parallel manuscripts (see Miller, Studies, 107-8).
} 
Akkadian (or Hurrian) Vorlage or whether perhaps the scribes are imitating a Mesopotamian style. ${ }^{33}$

In evaluating the attributions to named ritualists, a range of plausible positions can be offered, ranging from total skepticism regarding the authenticity of the attributions to lesser or greater confidence that the main body of the ritual text was dictated by the ritualist, though perhaps reworked or reformulated by a scribe. ${ }^{34}$ Late twentieth century Hittitological research tended towards a more maximal assessment, based on the assumption that the ritual text was based on dictation or an interview with the ritualist. For example, Cornil suggested that the $3^{\text {rd }}$ person formulas reflect a scribal tampering with the $1^{\text {st }}$ person accounts upon which the texts were based, transforming these interviews into ritual prescriptions. ${ }^{35}$

Recently, however, more attention has been given to the possibility that much of the materials ascribed to named ritualists was composed by the scribes themselves. Possible support for this more skeptical position can be found in the fact that, in at least six cases, it

${ }^{33}$ For the former possibility, see Miller, Studies, 507-8; for the latter: Torri, "Subject Shifting."

${ }^{34}$ For a detailed discussion of this problem with references to earlier literature, see Miller, Studies, 469-532.

35 “La tradition écrite des textes magiques hitittes." Ktema 24 (1999) 7-16. 
appears that the scribes were confused regarding the gender of the ritualist. ${ }^{36}$ That is to say, ritualists such as Ammihatna and Hูantitaššu, appear sometimes with both male and female determinatives in different text copies. Yet the ignorance of later scribes regarding the gender of earlier ritualists could be taken as evidence for the contrary position, namely that these ritual traditions have a long transmission history, resulting in inevitable distortions ('noise') in the transmission of certain details.

A more substantial argument may be raised based on the form of the attribution formulas. Recognizing the conventional nature of the $1^{\text {st }}$ person forms in the incipits, colophons, and often recurring at fixed points in the body of the ritual texts - specifically in the introduction of paraphernalia lists and incantation formulas, these appear to be scribal conventions which cannot automatically be assumed to be based on actual dictation from the ritual expert. ${ }^{37}$ Furthermore, the name attributions of the various compositions served as the key datum in the composition of shelve lists by which the textual inventory of the Hittite archives was recorded. ${ }^{38}$ The recognition of the scribal character of these conventions raises the possibility (at least) that the scribes may have added them to anonymous prescriptive texts formulated in the third person.

${ }^{36}$ For this argument, see Miller, Studies, 478, based on the data listed on 488-92. While acknowledging that some instances may simply be scribal errors, Miller contends that the number of incidents is too high to be explained as copying errors.

${ }^{37}$ Miller, Studies, 493-6.

${ }^{38}$ Gordin, Hittite Scribal Circles, 115. 
Moreover, as noted, Miller has found inconsistencies between the lists of paraphernalia and the ritual instructions. Many of these inconsistencies may be attributable to copying mistakes - or seemingly more likely - errors in recall, as when the materials associated with a keldi ritual (A ii 58) seem to be better suited to a zurki ritual, and in fact appear earlier in the text in that context (A ii 7). ${ }^{39}$ Yet the curious fact remains, mentioned earlier, that on multiple occasions the paraphernalia lists continue the $1^{\text {st }}$ person employed in the incipits and colophons. ${ }^{40}$ Does this point indicate that the paraphernalia lists were originally independent texts (written/ dictated by the ritualists themselves), or are these attributions merely scribal conventions, reverting in these sections to the first person forms employed in the incipits and colophons?

Miller also calls attention to two Syrian ritualists, Allaituraḩhi of Mukiš and Giziya of Alalah. ${ }^{41}$ Casting doubt on the 'observe and record' hypothesis, Miller argues that the Hittite versions of these rituals from the Hattuša archives may have been based on earlier (Hurrian? $^{42}$ compositions in the Kizzuwatna archives:

In any case, that it is unlikely that any Hittite scribe ever 'interviewed' Allaiturahhi, as suggested above, might also support the proposition that Hittite scribes felt little

\footnotetext{
${ }^{39}$ Miller, Studies, 404-405.

${ }^{40}$ Miller, Studies, 493-6.

${ }^{41}$ Studies, 506-11.

${ }^{42}$ See KUB 45.21, written almost exclusively in Hurrian, and attributed to her (Haas, "Die hurritisch-hethitischen Rituale," 126; Torri, "Subject Shifting," 677).
} 
remorse in ascribing various rituals and incantations to a ritualist of some fame in order to lend their compositions legitimacy. ${ }^{43}$

Further evidence for questioning some ritual ascriptions has been amassed by Birgit Christiansen in her study of the Ambazzi rituals. In particular, the situations to be addressed in CTH 463 appear to be taken from oracular texts that are similar to the Mesopotamian šumma $\bar{a} l u$ oracle series. As such, it seems more likely that this ritual is a product of scribal circles than originating from the ritual practitioner herself. ${ }^{44}$ Indeed, it is far from clear that the female Hittite ritualists (ŠU.GI; 'old woman') were literate in Hittite cuneiform, not to mention Akkadian, given that all of the known Hittite scribes were male. ${ }^{45}$

Yet it would appear that some of this skepticism is exaggerated. None of the evidence cited leads to the conclusion that the ritualists were mere literary inventions of the scribes (pseudonyms), employed to assert the effectiveness of the ritual ${ }^{46}$ For example, Miller's emphatic denial that Allaituraḩhi was a ŠU.GI, used to deny her authorship of the rituals in her name is contradicted by an explicit statement in KUB 24.13 III 18' (ChS I/5

\footnotetext{
${ }^{43}$ Miller, Studies, 509.

${ }^{44}$ Christiansen, Die Ritualtradition, 303-4, 316-17.

${ }^{45}$ Miller, Studies, 479. It should be noted, however, that other scholars have assumed that the ŠU.GIs were both literate and multi-lingual (for example: T. Bryce, Life and Society in the Hittite World [Oxford, UK: Oxford University Press, 2002] 201-2).

${ }^{46}$ As suggested by Hecker, "Tradition," 248-9.
} 
text 15$).{ }^{47}$ More generally, it is noteworthy that rituals attributed to a single "author" reflect common characteristics, which suggests at the very least that they originated in a single stream of tradition, if not derived from a common author. ${ }^{48}$ Moreover, as Miller himself points out in an important caveat, some genealogical information is given for at least two ritualists, suggesting that these figures were not literary inventions ex nihilo. ${ }^{49}$ Hence, there are grounds to adopt a more balanced view, such as that recently voiced by Gordin:

Even if...some 'authors' were legendary pseudonyms, many others are known from a variety of sources outside ritual traditions, like the late $13^{\text {th }}$-century scribe Armaziti, the $14^{\text {th }}$-hierodule Kuwatalla, and so on. Without questioning the author's role in producing the original composition (through dictation or otherwise), it is clear that some ritual and magical traditions existed at a remove in time or space from the producers of the late $13^{\text {th }}$-century copies and editions. This situation increased exponentially the position of the scribes in the collection, study, edition, and creation of these texts based on previous sources. ${ }^{50}$

${ }^{47}$ See V. Haas, Review of Studies in the Origins, Development and Interpretation of the Kizzuwatna Rituals, by J.L. Miller, Wiener Zeitschrift für die Kunde des Morgenlandes 95 (2005) 441.

${ }^{48}$ Christiansen, Die Ritualtradition, 317.

${ }^{49}$ Studies, 478, n. 803.

${ }^{50}$ Hittite Scribal Circles, 115. It should be kept in mind nevertheless that these examples (Armaziti, Kuwatalla) are rather exceptional. 
In other words, the recognition of a high level of scribal involvement does not contradict the assumption that these traditions originated with earlier ritual experts. On the contrary, it is to be expected that the evidence for scribal activity will increase in correlation to the length of transmission history of a particular ritual tradition.

Further evidence supporting such an approach can be adduced from several recent studies which identify language interference stemming from difficulties in translating Hurrian and Luvian terms and grammatical forms into Hittite. ${ }^{51}$ These studies suggest that the Hittite ritual texts from the Hattuša archives were based on earlier traditions (whether oral or written) in Hurrian and Luwian. Such evidence corroborates Miller's more moderate suggestion "[t]hat the earliest Allaiturahhi composition(s) may have been derived from texts composed already in northern Syria" and later appropriated by Kizzuwatnean scribes. ${ }^{, 52}$

\subsection{Summary: Scribal Activity and the Hittite Rituals}

${ }^{51}$ Taracha, "Hittite Rituals"; E. Rieken, "Sprachliche Merkmale religiöser Textsorten im Hethitischen," WdO 44 (2014) 162-173. For a sophisticated use of linguistic criteria applied to the tradition-history of Hittite rituals reflecting Luvian influence, see H.C. Melchert, "Luvian Language in 'Luvian' Rituals from Hattuša," in Beyond Hatti: A Tribute to Gary Beckman (ed. B.J. Collins and P. Michalowski; Atlanta: Lockwood Press, 2013). $159-72$.

${ }^{52}$ Studies, 507. 
In sum, the problem of the authorship of the Hittite rituals is far from settled, and progress will only be made by further detailed research on particular ritual compositions and the relationship between them. In the meantime, an intermediate position between blind credulity and categorical skepticism seems warranted. More fundamentally, it is necessary to recognize that conservatism aiming at preserving efficacious ritual traditions and innovation motivated by formal, literary, religious, or ideological purposes of the scribes are not mutually exclusive tendencies.

\section{The Purpose of the Hittite Ritual Texts}

It has come time to address the second line of inquiry: What were the functions of the Hittite ritual texts? To answer this question, it will be necessary to characterize the interaction between ritual text and practice. The following possibilities (not mutually exclusive) warrant consideration:

1) Memorization to facilitate ritual performance

2) Preservation of traditions

3) Enactments of authority

4) Production of 'new' rituals

5) Regulation of 'legitimate' practice

\subsection{Rituals Texts as Short-Term Memory Aids}


Despite the growing emphasis in recent research on the scribal character of the Hittite ritual texts ${ }^{53}$ one must not assume that they were divorced from practical use in ritual performance. Indeed, numerous characteristics of the texts themselves support the assumption that they were used as "aide-mémoires" for officiants. On this point, there is a basic similarity to the function of ritual texts elsewhere in the Levant, as can be seen from the Ugaritic evidence. ${ }^{54}$ For example, the deity list from Ugarit RS 24.264+ (KTU 1.118) corresponds to the sacrificial text RS 24.643 (KTU 1.148). This correspondence shows that the function of the deity lists was to ensure that each deity received his due, as indicated by the check marks on the left margins of RS $24.264+.{ }^{55}$ Hence, despite claims these deity lists served a "theological" purpose, there is little doubt that they served a practical function. A similar function is filled by the kaluti- lists in Hittite rituals,${ }^{56}$ as noted in the publication of one of these texts from Šapinuwa:

Unlike most of the cult texts that indicate the quantities and types of offerings dedicated to the gods, these tablets, at least in the preserved parts, do not contain such information, but only the long lists of deities, mountains, rivers and "Opfertermini" and some sections in Hurrian of unknown meaning... Nevertheless

${ }^{53}$ Summarized by Christiansen, Die Ritualtradition, 1-30.

${ }^{54}$ Pardee, Ritual and Cult, 2.

${ }^{55}$ M. C. A. Korpel, "Unit Delimitation in Ugaritic Cultic Texts and Some Babylonian and Hebrew Parallels," in Layout markers in biblical manuscripts and Ugaritic tablets (eds M.

C. A. Korpel and J.M. Oesch; Assen: Koninklijke Van Gorcum, 2005) 141-60.

${ }^{56}$ See R. Strauß, Reinigungsrituale aus Kizzuwatna (Berlin: de Gruyter, 2006) 159-65. 
the presence of some brief ritual instructions in Hittite demonstrates that these texts are not pure and simple lists of deities rivers, mountains and "Opfertermini", but in all likelihood a cult memorandum. ${ }^{57}$

Furthermore, as noted by Dennis Pardee in reference to the Ugaritic corpus, the laconic nature of ritual texts, especially regarding the precise procedures implied by a particular technical term, is based on the presumption that the priests needed no instructions for such routines ${ }^{58}$. Jared Miller makes a similar observation regarding the Ritual for Expanding the Night Goddess' Cult (CTH 481), "Indeed, it is striking that hardly any description of the ritual performances is to be found in the entire composition, in stark contrast to the sometimes voluminous lists. ${ }^{.59}$ His cogent suggestions regarding the Sitz im Leben of this text can illuminate our understanding of this textual genre as a whole:

These...phenomena reinforce the hypothesis that this composition could hardly have served as the 'script' according to which such a ritual was carried out, for which it would be seriously insufficient. Neither does it seem to constitute the work of a scribe or scribes assigned to observe and describe in writing ceremonies as they took place, as such a composition would surely show more consistency in its attempts to list the materials collected for the rites and then their use in those rites. Rather, as mentioned, the composition seems to constitute the 'notes' jotted down

\footnotetext{
${ }^{57}$ M. Giorgieri, L. Murat, and A. Süel, "The Kaluti-List pf the Storm-God of Šapinuwa from Ortaköy (Or. 90/175) and its Parallels from Boğazköy,” Kaskal 10 (2013) 174.

${ }^{58}$ Ritual and Cult, 26.

${ }^{59}$ Studies, 402.
} 
and/ or copied from other sources...in preparation for the execution of the expansion that they planned. In it they noted the primary events that were to take place, and in many cases, the items needed for them. Completeness and full consistency was not attempted, as the rites themselves were likely carried out not by reading from a 'script', but from memory, the present composition serving as a memory aid before the execution of the rites. ${ }^{60}$

In sum, the literary characteristics of the Hittite ritual texts, like those from Ugarit, suggest their use as guides to correct performance. ${ }^{61}$

\subsection{Long-term Preservation of Tradition}

The conservatism of cultic practice is widely acknowledged, so it is hardly surprising that ritual texts were used to preserve traditions for later generations. Several colophons of festival texts offer salient expression of this dimension of textualization. For example, the colophon of CTH 628 reads: "When queen Puduhepa commanded Walwaziti, the chief of scribes, to seek in Hattuša for tablets of Kizzuwatna, on that day he copied these tablets of the Festival of hišuwa." ${ }^{.62}$ The need for a textual record of ritual practice became especially urgent when the stability of cultic practice was disrupted by warfare

\footnotetext{
60 Ibid.

${ }^{61}$ See further Schwemer, "Quality Assurance Managers," 19-20; J. W. Watts, "Ritual Legitimacy and Scriptural Authority,” JBL 124 (2005) 404-412.

${ }^{62}$ Gordin, Hittite Scribal Circles, 41, 153; also Waal, The Source as Object, 286.
} 
and/ or foreign conquest. Such a situation is expressed clearly in the colophon of KUB 28.80: "Tablet of the recitation of the regular festival of Nerik. (This is) now a new tablet. When in the years of w[a]r they started to perform the festival of Nerik in Hakmiš, the man of the Stormgod (and) the GUDU-priest...came from Nerik and they took this re[cit]ation from those (refugee priests)" (rev. IV 1'-9'). ${ }^{63}$ Following an invasion by the Kaška tribes, this text records the traditions as dictated by the refugee priests of Nerik with the goal of reproducing the cultic practices in Hुakmiš.

\subsection{Ritual Texts and Authority}

At this point, it is important to clarify the relationship between textualization of ritual and authority. The reproduction of ritual texts in duplicate copies would seem to imply a certain significance to the verbal formulation of the ritual text, yet it remains necessary to determine: What was the motivating force for this scribal activity?

In this discussion, it seems appropriate to distinguish between therapeutic rituals festival (cultic) texts. Regarding the former, as is clear from the numerous variations between parallel manuscripts, these texts were not treated with scriptural sanctity, ${ }^{64}$ nor

\footnotetext{
${ }^{63}$ Waal, Ibid., 293; also Schwemer, “Quality Assurance Managers,” 13.

${ }^{64}$ See G. Beckman, Review of Die Ritualtradition der Ambazzi: Eine philologische Bearbeitung und entstehungsgeschichtliche Analyse der Ritualtexte CTH 391, CTH 429 und CTH 463, by B. Christiansen, JAOS 127.3 (2007) 375.
} 
were they ascribed directly to divine revelation like Mesopotamian incantations. ${ }^{65}$ Rather, the raison d'être of therapeutic ritual texts and their source of authority was their pretense to efficacy in achieving their aims.

In comparison, festival texts would seem to be governed by the concern for meticulous fulfillment of the kingdom's obligations vis-à-vis the gods and avoiding the potentially catastrophic neglect of these obligations. Nevertheless, the concern for detail in these texts regarding the correct procedure and sequence as determined by legitimate traditions, involving consultation of 'ancient' (annala- / karuili-) tablets, and modified by consultation with the gods via divination show that the ultimate function of the text was realizing the ideal of proper observance. In order to realize their purpose of paying homage to the gods, it was sometimes necessary - especially when changes were made - to seek divine approval by means of oracle inquiries. ${ }^{66}$ Hence, festival texts like other ritual texts were subordinate to practice, though the textualization of ritual could have additional functions and implications, as will be discussed below.

\subsection{Production of 'New' Rituals}

${ }^{65}$ O. R. Gurney, O. R. Some Aspects of Hittite Religion (Oxford: Oxford University Press, 1977) 44; R. Schmitt, Magie im Alten Testament (AOAT 313; Münster: Ugarit Verlag, 2004), 67-106.

${ }^{66}$ Schwemer, "Quality Assistance Managers." 
This focus on efficacy should also illuminate our consideration of rituals as scholarly literature. Obviously, the term "literature" does not imply an interest in the aesthetic value or the 'drama of reading' ritual texts, but simply their role in promulgating tradition. ${ }^{67}$ Specifically, the intense scribal activity involved in producing these texts was motivated first and foremost by the belief in the efficacy of the rituals themselves, which invited the scribes to expand the texts by contributing their own knowledge of ritual and divinatory corpora. It also encouraged consultation with Babylonian scribes and scribal works pertaining to the fields of ritual medicine, and this veneration is amply attested in the Hattuša archives. ${ }^{68}$

${ }^{67}$ P. Taracha, "Hittite Rituals as Literary Texts. What do we know about their original editions?" in Hethitische Literatur. Überlieferungsprozesse, Textstrukturen, Ausdrucksformen und Nachwirken. Akten des Symposiums vom 18. bis 20. Februar 2010 in Bonn (ed. M. Hutter and S. Hutter-Braunsar; AOAT 391. Munster: Ugarit-Verlag, 2011) 275-83; see also Gordin, Hittite Scribal Circles, 73-80.

${ }^{68}$ See Strauß, Reinigungsrituale, 208-15; D. Schwemer, "Gauging the Influence of Mesopotamian Magic: The Reception of Babylonian Ritual Traditions in Hittite Practice," in Diversity and Standardization: Perspectives on Ancient Near Eastern Cultural History (ed. E.C. Cancik-Kirschbaum, J.W. Klinger, and G.G.W. Müller; Berlin: de Gruyter, 2013) $145-72$. 
As noted above, Christiansen has suggested that CTH 463 appears to makes use of oracular texts that are similar to the Mesopotamian šumma $\bar{a} l u$ oracle series. ${ }^{69}$ A similar phenomenon can be found in Mesopotamian Namburbi rituals which often refer directly to specific omens known from divinatory texts. ${ }^{70}$ In short, it would appear that scribes could draw on multiple sources of authority in composing ritual texts, with the primary concern being the efficacy of the final result.

\subsection{Regulation of Legitimate Practice}

Yet aside from the efficacy of the ritual performance, it need not be denied that the textualization of ritual had important secondary implications. In particular, the ritual text served as an expression and enactment of the Hittite sovereign's authority, especially as represented by the hierarchy of court scribes. A vivid picture of these cult politics in action can be seen in the text KUB 32.133. This unique document deals with the aftermath of a cult reform by King Tudhaliya, who made a new temple for the Night Goddess in Šamuha modeled after her cult in Kizzuwatna. ${ }^{71}$ This text records Tudhaliya's descendent, Muršili

${ }^{69}$ Christiansen, Die Ritualtradition, 303-4, 316-17.

70 See S.M. Maul, Zukunftsbewältigung (Baghdader Forschungen 18; Mainz: Zabern, 1994).

${ }^{71}$ For the historical background of this text, see Miller, Studies, 350-62. For an edition of the related ritual text KUB 29.4, see ibid., 259-440. An insightful analysis of the religious 
II, complaining that the local scribes of Šamuha have corrupted the practice of the Night Goddess' cult:

Thus (says) His Majesty, Muršili, Great King, son of Šuppiluliuma, Great King, Hero: When my forefather, Tudhaliya, the Great King, split the Night Goddess from the temple of the Night Goddess in Kizzuwatna and worshipped her separately in a temple in Šamuha, those rituals and obligations that he ordained for the temple of the Night Goddess, the scribes-on-wood and the temple personnel came and began to incessantly alter them. I, Muršili, Great King, have reedited (EGIR-pa aniyanun) them from the tablets. Whenever in the future, in the temple of the Night Goddess of Šamuha, either the king, the queen, prince or princess come to the temple of the Night Goddess of Šamuha, these shall be the rituals. ${ }^{72}$

This text relates that Tudhaliya had "ordained" (hamankatta) the rituals for the Night Goddess, implying the royal authorization for the new cult in Šamuha, though it seems reasonable to assume that the rites were based for the most part on the earlier rites as practiced in Kizzuwatna. Apparently, the local priests and scribes of Šamuha did not wholeheartedly embrace Tudhaliya's cultic reform and made numerous changes in the (written) ritual. Alternatively, it is possible that the text implies that the Šamuha scribes lacked access to the original written ritual text, so that they proceeded to produce their own.

background of these texts can be found in R. Beal, "Dividing a God," in Magic and Ritual in the Ancient World (ed. P. Mirecki and M. Meyer; Leiden: Brill, 2002) 197-208.

${ }^{72}$ Adapted from Miller, Studies, 312-3. 
In response, Muršili here claims to restore his forefather's ordinance on the basis of the original tablets.

According to the former interpretation, involving a deliberate modification of written ritual instructions, it may significant that the king singles out for rebuke the "scribes-on-wood" (DUB.SAR.GIŠ). These scribes can be distinguished from "cuneiform scribes" (DUB.SAR) in that the former's function was "of a more clerical or secretarial nature." ${ }^{73}$ In other words, the fact that these secretaries were meddling with the content of the ritual texts was a violation of the scribal hierarchy and ultimately of royal authority. Accordingly, this passage may offer evidence for the competition between different loci of authority in the determination of 'legitimate' cult practice, with the Hittite monarch struggling to establish his authority over the conservatism of local cult officiants. ${ }^{74}$

${ }^{73}$ Gordin, Hittite Scribal Circles, 140. For further discussion of the use of wooden tablets and related terminology, see Ibid., 17-21 and 140-5 (on the scribal hierarchy); Schwemer, "Quality Assurance Managers," 11-12, 21-22. Regarding the debate concerning the designation DUB.SAR.GIŠ, see also T. P. J. van den Hout, "llúDUB.SAR.GIŠ = 'Clerk’?” OrNS 79 (2010) 255-67; W. Waal, "They Wrote on Wood: the Case for a Hieroglyphic Scribal Tradition on Wooden Writing Boards in Hittite Anatolia," Anatolian Studies 61 (2011) 21-34.

${ }^{74}$ Another example of the exercise of royal authority over the cult is Tudhaliya IV's edict regarding the cult of Nerik, which includes detailed instructions for ritual performance (Součková 2010). 
Importantly, the arena for this battle is the ritual text, with scribes acting as the mediators in attempts to 'fix' ritual tradition in an authoritative form.

The legitimizing function of ritual texts raises an additional question pertaining to the relationship between ritual text and practice. Here the question 'which came first' has interesting implications. For example, according to the view that takes the ritual text to be the progenitor of ritual practice one might understand the above cited evidence for the use of ritual texts as imposing royal authority over the cult as implying the monarch has 'authored' the ritual, or at least that the ritual derives its initial authority from the royal enactment. However, in most cases, as argued above, ritual texts were ancillaries to already existing ritual practice. Hence, one may contrast two schemes for reconstructing the source of authority of ritual texts:

1) Royal/ priestly authority $>$ text $>$ practice

2) Practice $>$ text $>$ royal/ priestly authorization

A recognition of the greater appropriateness of the second model (in most cases) enables a refined appreciation for the functions of ritual texts as texts. Specifically, an important role is the function of the text as a 'filter' by which authoritative practice is distinguished from 'illegitimate' variations, as can be seen from Muršili II's enactment. While the king was the highest mortal authority in the regulation of cultic practice, often he was required to defer to the gods for the final authorization of any changes by means of oracular inquiry. ${ }^{75}$

\footnotetext{
${ }^{75}$ Schwemer, "Quality Assurance Managers," 17-18.
} 
An even more heavy-handed use of ritual texts as expressions of royal authority can be found in the "Anatolian" rituals from Emar which were copied in the period of Hittite hegemony (13 ${ }^{\text {th }}$ cent. BCE). Significantly, the "diviner" (LÚ HAL) Zū-Ba'la, whose subordination to Hittite authorities is well documented, was the key scribe in whose personal archive were found most of the important ritual and festival texts from Emar. ${ }^{76}$ These texts sought to ensure the worship of the Hittite deities in Emar, as explicitly stated in the opening lines of one text: "The ritual tablet (tuppu parși) for the gods of the land of Hatti, the lower and upper cities." ${ }^{, 77}$ Further evidence for the role of Zū-Ba'la's family in the administration of the Emar cult makes clear that these ritual texts were intended to be implemented in actual practice. In other words, these ritual texts served as a medium of long-distance control for implementing Hittite authority in Emar. ${ }^{78}$

\subsection{Summary: Functions of Hittite Ritual Texts}

In sum, it seems that the primary function of the Hittite ritual texts was to serve as aids to ritual performance, namely as short-term memory aids to officiants. At the same time, this practical motive for textualization did not preclude additional functions,

${ }^{76}$ D. E. Fleming, Time at Emar. The Cultic Calendar and the Rituals from the Diviner's House (Winona Lake, IN: Eisenbrauns, 2000) 13-47; Y. Cohen, "The Administration of Cult in Hittite Emar," AoF 38 (2011) 145-57.

${ }^{77}$ Cohen, Ibid., 146.

${ }^{78}$ Cohen, Ibid., 150; P. M. Michel, Le culte des pierres à Emar à l'époque hittite (OBO 266. Fribourg : Academic Press/ Göttingen : Vandenhoeck \& Ruprecht, 2014). 
including the long-term preservation of ritual traditions, imposition of royal authority over local cults and regulation of legitimate practice.

These conclusions, drawing on a broad survey of ritual and cultic materials, dovetail with two recent studies focusing specifically on the festival traditions. In his recent analysis of the function of festival texts, Daniel Schwemer concludes that "the various activities that were immediately connected with the practice of the cult provide a sufficient and plausible explanation for the large number festival texts and texts of related genres that have been found at Hittite sites; there is no reason to postulate any other rationale for the writing of these cuneiform texts" (2016: 23). Nevertheless, this functional perspective of ritual texts does not preclude the recognition that the textualization of ritual practice caused these written documents to take on a life of their own. Based on formal characteristics of Hittite festival texts and modern parallels, Brigitte Christiansen (2016), has shown how that they could serve as a means for the preservation and regulation of traditions, while enabling 'legitimate' adaptations under the strict control of cultic and royal authorities. ${ }^{79}$ As texts, these documents became subject to intensive scribal activity, involving both conservational processes to preserve ritual traditions as well as innovations which drew upon the scholarly milieu.

\section{The Textualization of Priestly Ritual in Light of Hittite Rituals}

\footnotetext{
${ }^{79}$ This point is also recognized by Schwemer, "Quality Assurance Managers," 16-19.
} 
It has now come time to explore how this body of research on Hittite ritual can shed light on the biblical Priestly source. As a first step, it seems useful to catalog some of the fundamental similarities and differences between these two corpora. On one hand, when comparing the Hittite rituals with biblical rituals for defined situations such as Lev 13-14 (for leprosy), Lev 16 (for defilement of the temple/ national catastrophe), or Num 5:11-31 for a suspected adulteress, one finds numerous formal similarities, including:

- Casuistic structure

- Chronologically arranged instructions

- Lists of paraphernalia

- Sometimes laconic references to the component rites of the ritual

Taken together with the similarities in content with extra-biblical rituals, these characteristics would support the form-critical hypothesis that the biblical texts originated as individual ritual instructions for specific circumstances, comparable to the Hittite prescriptive rituals.

On the other hand, one must not ignore the significant differences. The most outstanding difference is the fact that Priestly ritual is inextricably integrated into the Priestly narrative. This 'narrativization' of ritual is not merely a superficial framework into which ritual instructions have been clumsily added. Rather, the ritual instructions are permeated by the narrative setting of the wilderness Tabernacle, including of course the key role of Aaron as high priest. Much to the dismay of historical-minded scholars, and despite their sharpened scalpels ready to dissect the text into its composite layers, the 
degree to which this narrative framework is consistently maintained is striking, leaving few traces which can be identified as betraying the historical setting of the author(s).

A related point pertains to the nature of the textual evidence from the two corpora. The Priestly source as transmitted in the Pentateuchal text has not left us with duplicates of a particular text. The closest analogs would be the comparison of ritual laws in Ezek 44 and Lev 22, the parallel accounts (command/ implementation) of the inauguration of the Tabernacle (Ex 29/ Lev 8), or the sin-offering laws of Lev 4 and Num 15. The epigraphic evidence from Ketef Hinnom has provided us with amulets paralleling the priestly blessing of Num 6:22-27. One may add the significantly divergent text of the Tabernacle-building narratives of Exodus in the Septuagint. Ultimately, however widely we delineate our data set, these isolated cases offer limited insight into the prehistory of the Priestly texts. This state of affairs is in stark contrast to the existence of multiple duplicates to particular Hittite rituals, which exhibit the minor and major variations discussed above. While we might at first glance attribute this disparity between the biblical and Hittite corpora to the difference in perishability of the material employed by Israelite and Hittite scribes (parchment or papyrus vs. clay tablets), the material factor is probably not the most significant. Rather, it should be recognized that the absence (or near absence) of divergent ritual traditions in ancient Israel is not accidental. Like the ubiquity of the narrative framework in the ritual materials, so too the near absence of divergent Priestly traditions bespeaks a high level of control and authority governing the perpetuation of the Priestly source.

One may even wonder if this control finds expression in the relatively high uniformity of the Second Temple manuscripts of Leviticus, as suggested by Sarianna Metso, "It is plausible that the Jerusalem priesthood had carefully guarded the transmission 
of the text of Leviticus." ${ }^{~}$ While some scholars, such as Russell Hobson with reference to the $m \overline{\mathbf{i}} s$ pi manuscripts from Aššurbanipal's library, have suggested that textual control is a function of genre, ${ }^{81}$ the Hittite evidence shows that the veneration of ritual traditions is not inevitably expressed in textual uniformity.

Turning to an additional illuminating difference between Hittite and Priestly rituals, it was noted regarding the Hittite texts that references to particular rites are usually laconic, presupposing the prior knowledge of the officiating priest. This point is valid generally for Ugaritic and Mesopotamian rituals. From this perspective, the detailed instructions for carrying out different offerings in Leviticus 1-7 are anomalies. How can they be explained? Taking a more historicist perspective, we may surmise that these instructions

80 "Evidence from the Qumran Scrolls for the Scribal Transmission of Leviticus," in Editing the Bible. Assessing the Task Past and Present (ed. J.S. Kloppenborg and J.H. Newman; Atlanta: Society of Biblical Literature, 2012) 69. See also Rhyder's contribution to this volume.

${ }^{81}$ See R. Hobson, Transforming Literature into Scripture: Texts as Cult Objects in Nineveh and Qumran (Sheffield, UK: Equinox, 2012). Similarly, but with different reasoning, Kenneth Mathews writes regarding the uniformity of the textual traditions of Leviticus: "Narrative literature (e.g. Samuel), in which a smooth reading for storytelling is desired, will undergo textual activity to meet that goal. A different kind of textual activity occurs for descriptive or legal material, in which rigid formulaic patterns are more important and thus textual activity aims at textual uniformity" ("The Leviticus Scrolls (11QpaleoLev) and the Text of the Hebrew Bible." Catholic Biblical Quarterly 48 [1986] 199). 
were written down during the exilic period (or soon thereafter) when the rituals were no longer practiced to ensure the preservation of these traditions. Along a similar vein, perhaps these ritual texts were somehow expected to serve as a substitute for the actual practice (analogous to how the later rabbis interpreted institutionalized prayers as substitutes for the sacrifices) $?^{82}$ While such historical explanations are almost irresistibly tempting, one cannot rule out a more ideological motivation, whereby the detailed instructions of Lev 17 were intended to stress that the ritual procedures must conform to the divinely revealed instructions. The centrality of this view is represented not only in the repeated formula that the Tabernacle was made "as YHWH commanded Moses" (Ex 29; Lev 8), it is represented in the assertion that the tabernacle was created according to the "model" (תבנית) shown to Moses (Ex 25:9, 40; 26:30). ${ }^{83}$

A further dimension of comparison is the role of scribal intervention in the editing of the Priestly ritual texts. Biblical scholarship has adduced numerous fairly clear cases in

\footnotetext{
${ }^{82}$ For example: Num. Rab. 18:21.

${ }^{83}$ Of course, this attitude is not exclusive to the HB. Divine revelation of a temple plan is an ancient Near Eastern motif that can be traced back to the $3^{\text {rd }}$ millennium Gudea inscriptions and continued until the Neo-Babylonian period; see V. Hurowitz, I Have Built You an Exalted House: Temple Building in the Bible in Light of Mesopotamian and Northwest Semitic Writings. JSOT Supp 115. Sheffield: JSOT Press, 1992 168-170, passim. One may also compare Šamaš’s revelation of the proper form of his image (ușurti șalmīšu) in the Nabû-apla-idinna Inscription; see C. E. Woods, "The Sun-God Tablet of Nabû-apla-idinna Revisited," JCS 56 (2004) 85 (iii 19).
} 
which an earlier form of the text has been supplemented by Fortschreibung. Confining myself to some relatively uncontroversial cases, it is instructive to categorize the various motives which can be deduced from these additions.

\section{Lev 8:10-12}

As has been recognized, the reference to the anointment of the cultic paraphernalia is absent from the parallel account in Ex 29 and has been interpolated from Ex 40:9-13. From a purely literary standpoint, this interpolation could be characterized as a harmonization between the two texts. More fundamentally, however, it resolves a contradiction pertaining to their ritual ideology. Specifically, whereas Ex 29:36-37 mentions the anointment of the altar only as the final sanctifying phase of the ritual process, Ex 40:9-13 and the dependent interpolation in Lev 8:10-12 presume that appurtenances must be 'ritualized' before they can be used in the cult. ${ }^{84}$

\section{Lev 5:7-13; 12:8; probably also Lev 1:14-17}

In these passages, an editor has made special provisions for poor Israelites who could not afford the regular prescribed offerings. Clearly, these clauses are governed by a desire to

\footnotetext{
${ }^{84}$ Y. Feder, Blood Expiation in Hittite and Biblical Ritual: Origins, Context and Meaning (Atlanta, GA: SBL, 2011) 46-8.
} 
expand the inclusiveness of the cultic institution, so that every member of the community can bring his or her offering. ${ }^{85}$

\section{$\underline{\text { Lev 16:29-34 }}$}

In contrast with the opening verses of the chapter which warn Aaron from entering the sacred precinct "at any time" (v. 2), implying that the following ritual addresses an emergency situation, ${ }^{86}$ the summary at the end of the chapter in vv. 29-34a fixes the date at the $10^{\text {th }}$ day of the $7^{\text {th }}$ month. This textual addition serves to systematize the Israelite cult on two levels, routinizing the purification of the sanctuary on an annual basis and integrating this day into the festival calendar.

These examples allow a glimpse (albeit incomplete) into the types of concerns that prompted later editors to supplement earlier priestly instructions. Importantly, these appear to be dominated by notions of propriety related to the cult itself and an attempt to adapt earlier instructions to a broader socio-religious framework. When evaluating the rhetorical

\footnotetext{
${ }^{85}$ See Nihan, From Priestly Torah, 244.

${ }^{86}$ J. Milgrom, Leviticus (AB3; 3 vols.; New York: Doubleday, 1991-2001), 1.1012-13.
} 
thrust of these Priestly texts, it is important to weigh these institutionalized cultic concerns alongside any ulterior political or economic motives. ${ }^{87}$

A slightly different picture is achieved by considering the Holiness Source as a large-scale Fortschreibung of P. Alongside the additions noted above (many of which can be attributed to $\mathrm{H}$ ), one may detect an attempt to complement P's limited focus on the cult with a comprehensive scheme for the entire nation, apparently in dialogue with other law codes of the Pentateuch. ${ }^{88}$

Even here a certain similarity can be found with the Hittite ritual texts. As noted, the first-person attributions to ritual experts tend to appear in the incipits and colophons of the text, though the body of the rituals tend to be more heterogeneous in content. So too, one finds an intensity of scribal activity specifically in the margins of the Priestly source, not only in the incipits and colophons of particular ritual instructions, ${ }^{89}$ but also in the references to the literary framework "at Mt. Sinai" (בהר סיני) at the end of the Holiness

${ }^{87}$ Compare J. W. Watts, Ritual and Rhetoric in Leviticus (Cambridge, UK: Cambridge University, 2007); idem, Leviticus 1-10 (Historical Commentary of the Old Testament. Leuven: Peeters, 2013).

${ }^{88}$ Nihan, From Priestly Torah, 548-559; J. Stackert, “The Holiness Legislation and its Pentateuchal Sources: Revision, Supplementation, and Replacement,“ in The Strata of the Priestly Writings: Contemporary Debate and Future Directions (ed. S. Shechtman and J.S. Baden; Zürich: Theologischer Verlag, 2009), 187-204.

${ }^{89}$ See M. Fishbane, “Biblical Colophons, Textual Criticism, and Legal Analogies," $C B Q$ 42 (1980) 438-449. 
Code (Lev $25: 1 ; 26: 46)$ to include this body of laws as the conclusion of the Sinai revelation..$^{90}$

\section{Conclusion}

In summary, the recent explosion of research into the textualization of Hittite ritual offers fascinating prospects for understanding the formation of the Priestly source. Though these are only some first impressions on a topic that demands much more sustained research, I will venture a few observations. The similarity in form, content and function of between the two corpora suggest to me that they derive from a similar Sitz im Leben, as aids to ritual practice. Likewise, there is substantial evidence that these corpora were shaped by complementary processes of conserving ritual traditions while enabling necessary adaptations.

These similarities have important ramifications for understanding the origins of the Israelite ritual traditions. Too frequently, the discussion of extra-biblical parallels to biblical rituals is entangled with the question of dating P. That is to say, the identification of precursors to biblical rituals from the Late Bronze Age Levant (e.g. Emar, Hatti, Ugarit) is taken to contradict the dating of $\mathrm{P}$ to the Persian Period common among biblical scholars. ${ }^{91}$ The recognition that the perpetuation of ritual traditions mediated by text and

\footnotetext{
${ }^{90}$ See Nihan, From Priestly Torah, 551; Metso, “Evidence,” 71.

91 The same can be said about attempts to claim the antiquity of $\mathrm{P}$ based on these parallels, as boldly argued by M. Weinfeld, "Social and Cultic Institutions in the Priestly
} 
actual practice was a longue durée process shows that these positions need not be contradictory.

At the same time, the differences between the processes of transmission of Hittite and Israelite ritual traditions may be just as illuminating as their similarities. Indeed, the comparison of the evidence in our possession indicates that these two bodies of tradition went through very different processes of development. Whereas the Hittite archives have left us with abundant evidence of the messy process of promulgating ritual texts characterized by both accidents of the duplication process stemming from mechanical errors and deliberate changes made by the scribes, the Priestly text in our possession is much more homogeneous and coherent, particularly in adherence to its literary framework. While this characteristic of $\mathrm{P}$ warrants further investigation, it may be postulated provisionally that the strict control reflected in P's textualization of Israelite ritual traditions was motivated not only as a reference guide for priests, since this consideration governed also the Hittite ritual literature. Rather, P's textualization of ritual traditions seeks

Source against their Ancient Near Eastern Background," Proceedings of the Eighth World Congress of Jewish Studies (1983) 95-129. For a broader discussion of this issue, see my forthcoming essay "Pentateuchal and Ancient Near Eastern Rituals," The Oxford Handbook of the Pentateuch (eds. Joel Baden and Christophe Nihan; Oxford, UK: Oxford University). For a survey of some of these parallels, see Feder, Blood Expiation, 115-43. 
to legitimate these practices as rooted in divine revelation, ${ }^{92}$ but no less importantly, serving thereby to reject alternative 'illegitimate' traditions. ${ }^{93}$

In other words, the evidence for scribal intervention in revising the early Priestly materials reflects a concerted effort to adapt them to the literary, ideological and socioreligious agenda of their editors. As compared with Christian Frevel's proposal that Leviticus represents a compromise document between rival Persian Period sects,${ }^{94}$ the state of evidence reviewed here appears to be more consistent with the more conventional 'schism' account. In other words, the relatively 'immaculate' form of the Leviticus tradition would indicate that an already authoritative form of Leviticus was accepted by different sects, whether because the groups shared a common historical background or because they simply acknowledged the authority of the Jerusalem priesthood's text. On the other hand, if Leviticus was edited to serve as a compromise document, one would expect to find more evidence of a messy process of formation, reflecting the rival groups' participation in this process. So until missing Priestly scrolls are discovered in Qumran or

${ }^{92}$ For a discussion of revelation as a scribal strategy of legitimation, see Watts, "Ritual Legitimacy"; van der Toorn, Scribal Culture, 205-32.

${ }^{93}$ For an example of the role of Priestly instructions as a filter against illegitimate traditions, see Y. Feder, "Behind the Scenes of a Priestly Polemic: Leviticus 14 and its Extra-Biblical $\begin{array}{lllllll}\text { Parallels," Journal of Hebrew } & \text { Scriptures } & 15.4 & \text { (2015) } & 1-26\end{array}$ (http://www.jhsonline.org/Articles/article_207.pdf).

${ }^{94}$ This volume. 
elsewhere, we must assume that the Jerusalem priesthood's hegemony over Israelite ritual traditions was already established in the early Persian period.

\section{Bibliography}

Beal, R. "Dividing a God.” Pp. 197-208 in Magic and Ritual in the Ancient World. Edited by P. Mirecki and M. Meyer. Leiden: Brill, 2002.

Beckman, G. Hittite Birth Rituals. Studien zu den Boğazköy-Texten 29. Wiesbaden: Harrassowitz, 1983.

— Review of Die Ritualtradition der Ambazzi: Eine philologische Bearbeitung und entstehungsgeschichtliche Analyse der Ritualtexte CTH 391, CTH 429 und CTH 463, by B. Christiansen, JAOS 127.3 (2007) 375-76.

— The babilili-Ritual from Hattusa. Winona Lake, IN: Eisenbrauns, 2014.

Bryce, T. Life and Society in the Hittite World. Oxford, UK: Oxford University Press, 2002. 
Carr, D. M. Writing on the Tablet of the Heart: Origins of Scripture and Literature. New York: Oxford University Press, 2005.

— The Formation of the Hebrew Bible: A New Reconstruction. Oxford: Oxford University Press, 2011.

Christiansen, B. Die Ritualtradition der Ambazzi: Eine philologische Bearbeitung und entstehungsgeschichtliche Analyse der Ritualtexte CTH 391, CTH 429 und CTH 463. Studien zu den Boğazköy-Texten 48. Wiesbaden: Harrassowitz, 2006.

— “Ein Ensuhnungsritual fur Tuthaliya und Nikalmati? Betrachrungen zur Entstehungsgeschichte von KBo 15.10+." SMEA 49 (2007) 93-107

_ “ "Liturgische Agenda, Unterweisungsmaterial und rituelles Traditionsgut: Die hethitischen Festritualtexte in kulturvergleichender Perspektive.” Pp. 31-66 in Liturgie oder Literature: Die Kultrituale der Hethiter im transkulturellen Vergleich. Edited by G.G.W. Müller. Studien zu den Boğazköy-Texten 60. Wiesbaden: Harrasowitz, 2016.

Clemens, D. M. Sources for Ugaritic Ritual and Sacrifice. Vol. 1: Ugaritic and Ugarit Akkadian Texts. AOAT 284/1. Münster: Ugarit-Verlag, 2001. 
Cohen, Y. "The Administration of Cult in Hittite Emar," AoF 38 (2011) 145-57.

Collins, B. J. "The Place of KBo 13.145 in the Hantitaššu Text Tradition.” Pp. 63-74 in Beyond Hatti: A Tribute to Gary Beckman. Edited by B.J. Collins and P. Michalowski. Atlanta: Lockwood Press, 2013.

_ _Royal Co-option of a Popular Ritual: The Case of Hantitassu." Pp. 185-201 in Proceedings of the Eighth International Congress of Hittitology, Warsaw, 5-9 September 2011. Edited by P. Taracha and M. Kapełus. Warsaw: Agade, 2014.

Cornil, P. “La tradition écrite des textes magiques hitittes.” Ktema 24 (1999) 7-16 .

Dardano, P. Die hethitischen Tontafelkataloge aus Hattuša (CTH 276-282). Studien zu den Boğazköy-Texten 47. Wiesbaden: Harrassowitz, 2006.

De Martino, S. and Süel, A. The Third Tablet of the itkalzi Ritual. LoGisma: Torino, 2015. 
Delnero, P. "Memorization and the Transmission of Sumerian Literary Compositions," JNES 71 (2012) 198-208.

Feder, Y. Blood Expiation in Hittite and Biblical Ritual: Origins, Context and Meaning. Atlanta, GA: Georgia: SBL, 2011.

_ "Behind the Scenes of a Priestly Polemic: Leviticus 14 and its Extra-Biblical Parallels," Journal of Hebrew Scriptures 15.4 (2015) 1-26

(http://www.jhsonline.org/Articles/article_207.pdf).

_ _Pentateuchal and Ancient Near Eastern Rituals." In The Oxford Handbook of the Pentateuch. Edited by Joel Baden and Christophe Nihan. Oxford, UK: Oxford University, forthcoming.

Fishbane, M. "Biblical Colophons, Textual Criticism, and Legal Analogies," $C B Q 42$ (1980) 438-449.

Fleming, D. E. Time at Emar. The Cultic Calendar and the Rituals from the Diviner's House. Winona Lake, IN: Eisenbrauns, 2000. 
Giorgieri, M., Murat, L. and Süel, A. “The Kaluti-List pf the Storm-God of Šapinuwa from Ortaköy (Or. 90/175) and its Parallels from Boğazköy.” Kaskal 10 (2013) 169-83

Gordin, S. Hittite Scribal Circles: Scholarly Tradition and Writing Habits. Studien zu den Boğazköy-Texten 59; Wiesbaden: Harrassowitz, 2015.

Gurney, O. R. Some Aspects of Hittite Religion. Oxford: Oxford University Press, 1977.

Haas, V. "Die hurritisch-hethitischen Rituale der Beschwörerin Allaiturah(h)i und ihr literarhistorischer Hintergrund.” Pp. 117-44 in Hurriter und Hurritisch. Edited by V. Haas. Konstanzer Althistroische Vorträge und Forschungen 21. Konstanz: Xenia, 1988

— Review of Studies in the Origins, Development and Interpretation of the Kizzuwatna Rituals, by J.L. Miller. Wiener Zeitschrift für die Kunde des Morgenlandes 95 (2005) $435-41$.

Hobson, R. Transforming Literature into Scripture: Texts as Cult Objects in Nineveh and Qumran. Sheffield, UK: Equinox, 2012. 
Hurowitz, V. I Have Built You an Exalted House: Temple Building in the Bible in Light of Mesopotamian and Northwest Semitic Writings. JSOT Supp 115. Sheffield: JSOT Press, 1992.

Hecker, K. “Tradition und Originalität in der altorientalischen Literature," Archív Orientální 45 (1977) 245-58.

Kassian, A., Korolëv, A. and Sidel'tsev, A. Hittite Funerary Ritual: šalliš waštaišs. AOAT 288; Münster: Ugarit-Verlag, 2002.

Korpel, M. C. A. "Unit Delimitation in Ugaritic Cultic Texts and Some Babylonian and Hebrew Parallels." Pp. 141-60 in Layout markers in biblical manuscripts and Ugaritic tablets. Edited by M. C. A. Korpel and J.M. Oesch. Assen: Koninklijke Van Gorcum, 2005.

Levine, B. A. "Ugaritic Descriptive Rituals," JCS 17 (1963) 105-11.

— “The Descriptive Tabernacle Texts of the Pentateuch," JAOS 85 (1965) 307-18. 
_ “The Descriptive Ritual Texts from Ugarit: Some Formal and Functional Features of the Genre." Pp. 467-475 in The Word of the Lord Shall Go Forth: Essays in Honor of David Noel Freedman in Celebration of his Sixtieth Birthday. Edited by C.L. Meyers and M. O’Connor. Winona Lake: Eisenbrauns, 1983.

Marcuson, H. and van den Hout, T. "Memorization and Hittite Ritual: New Perspectives on the Transmission of Hittite Ritual Texts." JANER 15 (2015) 143-68.

Mathews, K. A. "The Leviticus Scrolls (11QpaleoLev) and the Text of the Hebrew Bible." Catholic Biblical Quarterly 48 (1986) 171-207.

Maul, S. M. Zukunftsbewältigung. Baghdader Forschungen 18; Mainz: Zabern, 1994.

Melchert, H.C. “Luvian Language in 'Luvian’ Rituals from Hattuša,” Pp. 159-72 in Beyond Hatti: A Tribute to Gary Beckman. Edited by B.J. Collins and P. Michalowski. Atlanta: Lockwood Press, 2013.

Metso, S. "Evidence from the Qumran Scrolls for the Scribal Transmission of Leviticus." Pp. 67-79 in Editing the Bible. Assessing the Task Past and Present. Edited by J.S. Kloppenborg and J.H. Newman. Atlanta: Society of Biblical Literature, 2012. 
Michel, P. M. Le culte des pierres à Emar à l'époque hittite. OBO 266. Fribourg: Academic Press/ Göttingen : Vandenhoeck \& Ruprecht, 2014.

Milgrom, J. Leviticus. AB3; 3 vols.; New York: Doubleday, 1991-2001.

Miller, J. L. Studies in the Origins, Development and Interpretation of the Kizzuwatna Rituals. Studien zu den Boğazköy-Texten 46; Wiesbaden: Harrassowitz, 2004.

— Review of Die Ritualtradition der Ambazzi: Eine philologische Bearbeitung und entstehungsgeschichtliche Analyse der Ritualtexte CTH 391, CTH 429 und CTH 463, by B. Christiansen. ZA 99 (2009) 153-57.

Nihan, C. From Priestly Torah to Pentateuch. Forschungen zum Alten Testament 2/25. Tübingen: Mohr Siebeck, 2007.

Pardee, D. Les textes rituels. Ras Shamra-Ougarit 12. Paris: Editions recherche sur les civilisations, 2000. 
Pardee, D. Ritual and Cult at Ugarit. Writings from the Ancient World 10. Atlanta: SBL, 2002.

Rieken, E. "Sprachliche Merkmale religiöser Textsorten im Hethitischen.” WdO 44 (2014) 162-173.

Schmitt, R. Magie im Alten Testament. AOAT 313. Münster: Ugarit Verlag, 2004.

Schwemer, D. "Gauging the Influence of Mesopotamian Magic: The Reception of Babylonian Ritual Traditions in Hittite Practice. Pp. 145-72 in Diversity and Standardization: Perspectives on Ancient Near Eastern Cultural History. Edited by E.C. Cancik-Kirschbaum, J.W. Klinger, and G.G.W. Müller. Berlin: de Gruyter, 2013.

__ “Quality Assurance Managers at Work: The Hittite Festival Tradition.” Pp. 1-29 in Liturgie oder Literature: Die Kultrituale der Hethiter im transkulturellen Vergleich. Edited by G.G.W. Müller. Studien zu den Boğazköy-Texten 60. Wiesbaden: Harrasowitz, 2016. 
Stackert, J. "The Holiness Legislation and its Pentateuchal Sources: Revision, Supplementation, and Replacement." Pp.187-204 in The Strata of the Priestly Writings: Contemporary Debate and Future Directions. Edited by S. Shechtman and J.S. Baden. Zürich: Theologischer Verlag.

Strauß, R. Reinigungsrituale aus Kizzuwatna. Berlin: de Gruyter, 2006.

Taracha, P. "Hittite Rituals as Literary Texts. What do we know about their original editions?" Pp. 275-83 in Hethitische Literatur. Überlieferungsprozesse, Textstrukturen, Ausdrucksformen und Nachwirken. Akten des Symposiums vom 18. bis 20. Februar 2010 in Bonn. Edited by M. Hutter and S. Hutter-Braunsar. AOAT 391. Munster: UgaritVerlag.

Torri, G. "Subject Shifting in Hittite Magical Rituals." Pp. 671-80 in Tabularia Hethaeorum. Hethitologische Beiträge. Silvin Košak zum 65 Geburtstag. Edited by D. Groddek and M. Zorman. Dresdner Beiträge der Hethitologie 25. Wiesbaden: Harrassowitz, 2007.

Van den Hout, T. P.J. "Death as a Privilege." Pp. 37-75. In Hidden Futures: Death and Immortality in Ancient Egypt, Anatolia, the Classical, Biblical and Arabic-Islamic World. 
Edited by J.M. Bremmer, T. van den Hout and R. Peters. Amsterdam: Amsterdam University Press, 1994

—_lúDUB.SAR.GIŠ = ‘Clerk'?” OrNS 79 (2010) 255-67.

_ _ “u einer Stratigraphie der hethitischen Totenrituale.” Pp. 301-6 in Saeculum. Gedenkschrift für Heinrich Otten anlässlich seines 100. Geburtstags. Edited by A. Müller-Karpe, E. Rieken, and W. Sommerfeld. Studien zu den Boğazköy-Texten 58. Wiesbaden: Harrassowitz, 2015.

Van der Toorn, K. Scribal Culture and the Making of the Hebrew Bible. Cambridge, MA: Harvard University Press, 2007.

Waal, W. The Source as Object. Studies in Hittite Diplomatics (Ph.D. diss., Leiden University, 2010).

— "They Wrote on Wood: the Case for a Hieroglyphic Scribal Tradition on Wooden Writing Boards in Hittite Anatolia.” Anatolian Studies 61 (2011) 21-34.

Watts, J. W. "Ritual Legitimacy and Scriptural Authority.” JBL 124 (2005) 401-41. 
—_Ritual and Rhetoric in Leviticus. Cambridge: Cambridge University, 2007.

- Leviticus 1-10. Historical Commentary of the Old Testament. Leuven: Peeters, 2013.

Weinfeld, M. "Social and Cultic Institutions in the Priestly Source against their Ancient Near Eastern Background," Proceedings of the Eighth World Congress of Jewish Studies (1983) 95-129.

Woods, C. E. “The Sun-God Tablet of Nabû-apla-idinna Revisited,” JCS 56 (2004) 23103.

Worthington, M. Principles of Akkadian Textual Criticism. Berlin: de Gruyter, 2012. 